\title{
CIRCUMNAVIGATING NON-EQUIVALENCE IN LEGAL LANGUAGES: A TRILINGUAL CASE STUDY OF GENERIC-SPECIFIC CONCEPTS AND TERMS
}

\author{
Sigita Rackevičienè, Violeta Janulevičienè, Liudmila Mockienè
}

Institute of Humanities, Mykolas Romeris University, Vilnius, Lithuania

E-mails: sigita.rackeviciene@mruni.eu; vjanul@mruni.eu; liudmila@mruni.eu

\begin{abstract}
Studies of Language for Specific Purposes (LSP) aim at mastering particular terms of the target discourse community in the given field of knowledge. This cannot be achieved without comprehending the concepts denoted by the terms and their genericspecific relations which is not always the case in popular usage by media and translation. The given research is a small-scale analysis of conceptualisation and denotation of bribery offences in different legal settings (the international conventions and three national legal systems - the UK, Lithuanian and Russian) intended to expose the way of circumnavigating non-equivalency for LSP/ESP (English for Specific Purposes) learners. Firstly, bribery concepts in two international conventions are analysed and their terminological denotations in English, Lithuanian and Russian versions of the conventions are extracted. Secondly, functional equivalents of the international bribery concepts (the generic concept of bribery and the concepts forming the dichotomies of bribery types and forms) in the UK, $L T$ and RU national legal settings are determined. Finally, terminological counterparts denoting the bribery concepts in the investigated legal settings are established. The analysis is performed using the methodology of contrastive conceptual analysis which focuses on logical relationship among the concepts, namely hierarchical genus-species relations, in lexical semantics referred to as hyper-hyponymic relations. The methodology enables to compare conceptualisation and denotation of bribery offences and highlight their incongruities. The procedure and the results described in the paper are believed to be valuable to the learners and teachers of LSP/ESP, to the translators and could enhance efficient international professional communication.
\end{abstract}

Key words: conceptual-terminological system, non-equivalence, legal terminology, bribery

\section{INTRODUCTION}

Mastering specific terms and, most importantly, comprehending the concepts denoted by the terms is one of the key issues in the Language for Specific Purposes (LSP) studies. Studies of language for law, public administration and related areas expose the learners to one more challenge - non-equivalence of concepts functioning in different languages or even within the same language used in different (international and national) settings.

It has been observed in practical English for Specific Purposes (ESP) classes the need and relevance of ESP learners' awareness raising in precise translation for genericspecific concepts which might be used synonymously in their native language. This 
continues to be a relevant topic not only in legal and public governance discourse, but also, though in a lesser degree, in the language of science and technology (Roche et al. 2009, 321).

The issue is of particular importance in law and governance where highly abstract concepts are referred to. This is also the case with the conceptualisation of one of the most widely discussed criminal activities nowadays - corruption. A closer analysis reveals that terms denoting corruption offences present difficulties for rendering them precisely into different European languages. A cultural factor might be decisive here, because "While steering away clear from cultural relativism, it is also important to bear in mind that different conceptions of corruption are found in different societies and among different groups and persons in the same society at any given time, raising the issue that the concept of corruption is not easily translated across cultures" (Pardo 2016, 3). Thus, conceptualisation of corruption and its types is different across legal settings of national states as well as international legal framework. That makes search for terminological counterparts in source and target languages particularly challenging both in translation of international and national documents.

The issues outlined call for the systematic study of the corruption related terminology in the international conventions and national legal acts in the English, Lithuanian and Russian languages. The Lithuanian language is the native tongue for the majority of our students in the Bachelor study programme ESP and the Second Foreign Language at Mykolas Romeris university, Vilnius, Lithuania. However, there is quite a substantial number of international students in our ESP study programme, mainly from the neighbouring countries, especially, from Byelorussia and Ukraine where Russian is the mother tongue or the second language of our learners.

Therefore, it is considered of utmost importance to circumnavigate non-equivalence of some cases of terminology and raise our learners' awareness to distinct conceptualterminological systems not only in different languages within their studied LSP, but also within the same language.

The aim of this paper is to present a case study of bribery terminology analysis, which might be used as an assignment for legal language/legal translation students with the aim to raise their awareness of the conceptual and terminological incongruities noticed in the approved international and national legal documents.

Objectives of the presented case study are:

- to examine the concept of bribery in the available trilingual sources and to select the legal documents necessary for the analysis;

- to examine the concepts of bribery offences and their terminological denotations in the English version of the selected international conventions and to establish their vertical (hierarchical) and horizontal (non-hierarchical) interrelations; subsequently, to extract the Lithuanian (LT) and Russian (RU) counterparts of the English terms from the Lithuanian and Russian officially approved translations of the conventions;

- to establish functional equivalents of the international bribery concepts (the generic concept of bribery and the concepts forming the dichotomies of bribery types and forms) in the UK, LT and RU national legal settings;

- to establish terminological counterparts denoting the bribery concepts in the investigated legal settings. 


\section{THEORETICAL BACKGROUND AND THE METHODOLOGY OF THE RESEARCH}

Translation of legal terminology is one of the most challenging translation tasks due to incongruity of legal conceptual systems in different legal settings (De Groot and van Laer 2007; Biel and Engberg 2013). Globalisation and international law add another dimension to legal translation. The international law has also developed its own conceptual system which generalises the conceptual knowledge of the legal frameworks worldwide and often does not coincide with a national legal conceptual system.

Therefore, both translators of international and national legal documents constantly encounter cases of conceptual non-equivalence. When dealing with them, both cognitive and communicative approach to translation are important. The translator is expected to possess sufficiently thorough knowledge of the relevant legal settings, their norms and conceptual systems. Alongside, the translator must assess the addressee of the target text, his/her framework of reference. When reading a translation of any given legal act, the target text reader will automatically establish links to the legal setting of his/her state and interpret the text according to the norms in that particular legal setting. Therefore, for the translator it is "of utmost importance to know what kind of knowledge the addressee of a translation will have with regard to legal concepts and norms" (Sandrini 2009, 43). Consequently, translators of international legal documents have a double task - to use the terminology which reveals the legal conceptual system of the international legal setting and which enables the user to establish links to the legal conceptual system of the national legal setting.

In order to achieve the most possible congruity between international and national terminology, terminologists perform contrastive analyses of relevant legal areas and thus establish the closest conceptual equivalents and their terminological denotations in different legal settings. Most national legal concepts are "system-bound" as they are embedded in the national legal acts which shape their meaning and determine their functioning. Hence, legal concepts will hardly ever contain the same content in different legal settings, they may only have functional equivalents performing similar, but not identical functions in other legal settings. Therefore, contrastive legal conceptual analysis requires interdisciplinary approach which is emphasized in the studies of legal translation: knowledge of a particular legal area in the source and target legal settings, principles of comparative law methodology, logical and ontological relationships among concepts, as well as development of knowledge organization systems and their comparison (cf. Šarčević 1997; Galdia 2003; Bajčić 2017).

The given research focuses on logical relationship among the concepts, namely vertical (hierarchical) relations and horizontal (non-hierarchical) relations. In vertical relationships, also called genus-species relationships, the concepts are categorised either as generic or specific according to the degree of their abstraction/inclusiveness. A generic concept is superordinate to specific concepts which respectively are subordinate to it. The generic concept is the most abstract and inclusive one - it encompasses characteristics of all specific concepts subordinate to it. In horizontal relationships, the concepts are at the same level of abstraction, they share basic characteristics, but have at least one additional characteristic that differentiate them from each other (cf. Cabré 1999, 100; Pamela (Ed.) 2012, 29, 57-59, 133; Bajčić 2017, 17).

Lexical semantics refers to this kind of relations as hyper-hyponymic ones. The terms referring to generic concepts are called superordinate terms or hypernyms while the terms referring to specific concepts are named hyponyms. The terms denoting the concepts at the same level of abstraction are referred to as co-hyponyms (Jackson and Ze Amvela2012; 
Šseškauskienė 2013). The vertical and horizontal conceptual-terminological classifications are knowledge organization systems of specific domains, they reveal specialised knowledge of a given domain and provide comprehensive information about the functions of the concepts in it.

The present research is a small-scale analysis of conceptualisation and denotation of bribery offences in different legal settings (the international setting and three national settings - the UK, Lithuanian and Russian). In the research, vertical and horizontal relations among bribery concepts are determined in the international legal setting and the functional equivalents of the international legal concepts are searched in the national legal settings aiming to compare conceptualisation of bribery offences and establish their terminological counterparts in different settings.

\section{CONTRASTIVE CONCEPTUAL-TERMINOLOGICAL ANALYSIS OF BRIBERY OFFENCES IN THE INTERNATIONAL AND NATIONAL LEGAL ACTS}

\subsection{The concept of bribery}

Bribery is the most common corruption offence and, therefore, is often used as a synonym of corruption though the concept of corruption is much broader and includes various types of offences in addition to bribery.

Transparency International, an international non-governmental organisation fighting corruption in the countries all over the world, defines bribery as: "The offering, promising, giving, accepting or soliciting of an advantage as an inducement for an action which is illegal, unethical or a breach of trust. Inducements can take the form of gifts, loans, fees, rewards or other advantages (taxes, services, donations, favours, etc.)" (TI Anti-Corruption Glossary, Entry Bribery). The definition reveals, that bribery encompass two types of activities: the ones performed by a briber towards a bribee (offering, promising, giving) and, vice versa, the ones performed by a bribee towards a briber (accepting, soliciting). Both types of bribery are extremely difficult to investigate as it is often a consensual act between the parties involved (OECD 2012).

Bribery is mostly associated with offences committed by public officials, i.e. 'privateto-public' bribery. However, in the last decades, 'private-to-private' corruption (including 'private-to-private' bribery) has been widely discussed as well: its nature, social and ethical consequences, the legal treatment it receives in different countries and the measures to combat it (Argandoña 2003). Transparency International also calls for attention to this type of bribery: "All national legislation should outlaw bribery between firms in the private sector" (TI Anti-Corruption Glossary, Entry Bribery). Thus, the concept of bribery is multidimensional: it encompasses various types of activities performed by persons holding various positions both in the public and private sectors.

\subsection{Analysis of the selected international conventions}

Two international conventions defining types and subtypes of corruption offences were selected for the research: The United Nations Convention against Corruption (2003) (further the UN Convention), The Council of Europe's Criminal Law Convention on Corruption (1999) (further the CoE Convention). Both conventions are multilateral agreements adopted by many states and translated into the official languages of the state parties. They are 
translated into Lithuanian and Russian. This enables to compare not only the conceptual system in the international and national legal settings, but also the terminological denotations in the English, Lithuanian and Russian languages used in the different legal settings.

The aim of the research is to establish the position of the concept bribery in the conceptual system of the international legal setting answering the following questions:

1) Which position does the concept of bribery take in the macro-system of corruption offences?

2) What micro-system of bribery offences does it generate?

\subsubsection{The position of the concept of bribery in the macro-system of corruption offences}

The selected international conventions are devoted to the overall phenomenon of corruption. Thus, the concept of corruption is used in them as a generic concept encompassing the whole class of concepts referring to various types of corruption offences positioned on the lower level of the conceptual hierarchy. The UN Convention defines 11 types of acts of corruption which are to be considered as criminal offences, while the CoE Convention enumerates 14 of them. The offences are differently categorised and denoted. Three types of offences are included in both UN Convention and CoE Convention are bribery, trading in influence and laundering of proceeds (the UN Convention, Chapter III; the CoE Convention, Chapter II).

Thus, the terms denoting corruption and corruption offences create a conceptualterminological macro-system. In this system, the term corruption functions as a hypernymic term which denotes the generic concept encompassing a broad category of offences denoted by co-hyponymic terms. The number of specific corruption offences and their denotations vary in the conventions, but the same systemic principle of hierarchical relations is observed. The term bribery takes a co-hyponym position in the hierarchy (see Figure 1).

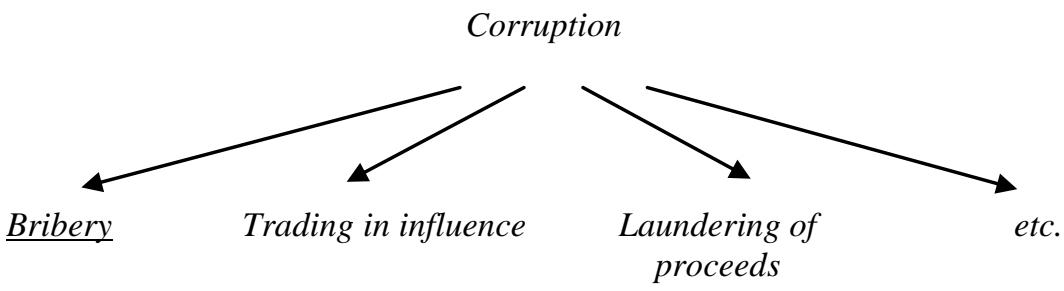

Fig. 1 Hierarchy of corruption offences in the UN and CoE Conventions

\subsubsection{Micro-system of bribery offences}

In both conventions, several subtypes of bribery are distinguished which create a conceptual-terminological micro-system within the whole conceptual macro-system of corruption offences. The bribery concepts of both documents form two clear dichotomies: bribery in the public sector vs. bribery in the private sector (further dichotomy 'public private') and active bribery vs. passive bribery (further dichotomy 'active - passive').

- The dichotomy 'public-private'

The dichotomy 'public-private' is formed by concepts referring to bribery activities in different sectors of economic life (public and private) including actors holding certain positions in these sectors. Bribery in the public sector concerns public officials holding 
positions in domestic, foreign and international public institutions and organisations. Meanwhile, bribery in the private sector concerns employers and employees in private entities: "any persons who direct or work for, in any capacity, private sector entities" (the UN Convention, Chapter III, Article 21, the CoE Convention, Chapter II, Articles 7-8).

The dichotomy 'public-private' is expressed by different terms in both conventions:

- Terms denoting bribery in the public sector:

There is no term denoting the overall concept of bribery in the public sector in the conventions. Instead, there are terms which denote specific subtypes of bribery in the public sector according to the types of public officials taking part in bribery activities. The types of public officials depend on whether they hold domestic, foreign or international office in an administrative, legislative or judicial branch. The UN Convention distinguishes 3 subtypes of corruption activities (bribery of national public officials, bribery of foreign public officials, bribery of officials of public international organisations) while the CoE Convention 7 subtypes of corruption activities (bribery of domestic public officials, bribery of members of domestic public assemblies, bribery of foreign public officials, bribery of members of foreign public assemblies, bribery of officials of international organisations, bribery of members of international parliamentary assemblies, bribery of judges and officials of international courts) (the UN Convention, Chapter 3, Articles15-16, the CoE Convention, Chapter 2, Articles 2-6, 9-11).

- Terms denoting bribery in the private sector:

Both conventions include the term bribery in the private sector (the UN Convention, Chapter III, Article 21, the CoE Convention, Chapter II, Articles 7-8).

- The dichotmy 'active-passive'

The dichotomy 'active-passive' is formed by the concepts referring to participants of the same bribery situation (briber and bribee), although performing different actions towards each other. The same dichotomy is present in bribery situations both in the public and in the private sector as defined in the CoE Convention, Chapter II, Articles 23, 7-8, cf. the UN Convention, Chapter III, Articles 15, 16, 21 :

- Public sector:

"the promising, offering or giving by any person, directly or indirectly, of any undue advantage to any of its public officials, for himself or herself or for anyone else, for him or her to act or refrain from acting in the exercise of his or her functions";

"the request or receipt by any of its public officials, directly or indirectly, of any undue advantage, for himself or herself or for anyone else, or the acceptance of an offer or a promise of such an advantage, to act or refrain from acting in the exercise of his or her functions".

- Private sector:

"the promising, offering or giving, directly or indirectly, of any undue advantage to any persons who direct or work for, in any capacity, private sector entities, for themselves or for anyone else, for them to act, or refrain from acting, in breach of their duties",

"the request or receipt, directly or indirectly, by any persons who direct or work for, in any capacity, private sector entities, of any undue advantage or the promise thereof for themselves or for anyone else, or the acceptance of an offer or a promise of such an advantage, to act or refrain from acting in breach of their duties". 
The dichotomy 'active-passive' is expressed by different terms only in the CoE Convention. Bribers actions are denoted by the term active bribery, while bribes actions by the term passive bribery (the CoE Convention, Chapter II, Articles 2-3, 7-8). In the UN convention, the concepts of this dichotomy are not denoted by separate terms though the concepts are described in separate paragraphs of the relevant articles (the UN Convention, Chapter III, Articles 15, 16, 21).

The analysis of the relations among bribery concepts reveals the structure of the micro-system of bribery offences which constitutes a part of the conceptual macrosystem of corruption offences. At the lexical level, the relations are expressed by the hypernymic term bribery and its hyponyms which in turn are superordinate to their hyponyms at lower levels. Highlighting the most important divisions according to the types of activities, the following scheme may be provided:
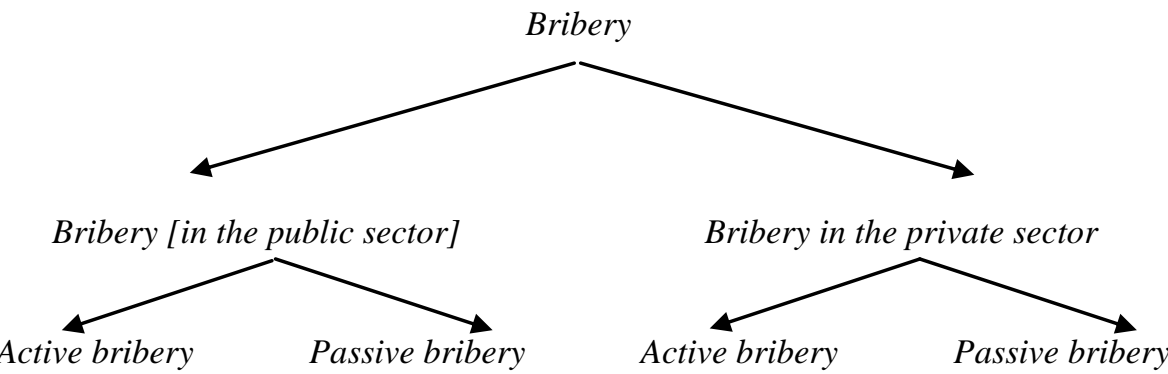

Fig. 2 Hierarchy of bribery offences in the UN and CoE Conventions

As it was pointed out above, the conventions do not include the term bribery in the public sector. Instead of it, they include the terms of separate subtypes of bribery offences according to the types of public officials involved in them. However, for the purposes of the research, the constructed terminological denotation (following the pattern of the formation of the term bribery in the private sector and including the term public sector used separately in the UN Convention, Chapter II, Article 7) is used in the paper.

\subsubsection{Terminological denotations of bribery related concepts in the Lithuanian and Russian}

Bribery related concepts have the following terminological denotations in LT and RU versions of the CoE conventions:

Table 1 Terms denoting bribery and its types in English, Lithuanian and Russian versions of the UN and CoE conventions

\begin{tabular}{|l|l|l|}
\hline EN & LT & RU \\
\hline Bribery & Kyšininkavimas & Подкуn \\
\hline Bribery [in the public sector] & $\begin{array}{l}\text { Kyšininkavimas } \\
\text { [valstybiniame sektoriuje] }\end{array}$ & $\begin{array}{l}\text { Подкуn [в публичнном } \\
\text { секторе] }\end{array}$ \\
\hline Bribery in the private sector & $\begin{array}{l}\text { Kyšininkavimas privačiame } \\
\text { sektoriuje }\end{array}$ & Подкуп в частном секторе \\
\hline Active bribery & Aktyvusis kyšininkavimas & Активный подкуn \\
\hline Passive bribery & Pasyvиsis kyšininkavimas & Пассивный подкуn \\
\hline
\end{tabular}


The terminological denotation follows the same principles in all three languages - the hypernymic term bribery which denotes the generic concept is also used in the denotations of all subordinate concepts thus making the terminological system clear and transparent.

The subsequent analysis of the national legal settings aims at searching functional equivalents of:

- the generic concept of bribery and its terminological denotation;

- the concepts forming the dichotomy 'public - private' and its terminological expression;

- the concepts forming the dichotomy 'active - passive' and its terminological expression.

\subsection{Analysis of the national legal acts of the UK}

For the purposes of the research, the UK legal act named The Bribery Act 2010 (further the UK Bribery Act) was chosen. In addition, one more document was examined - the guidance of the same act named The Bribery Act 2010 - Guidance about procedures which relevant commercial organisations can put into place to prevent persons associated with them from bribing (further the Guidance).

The UK Bribery Act uses one generic concept encompassing all types and forms of bribery offences, it is denoted by the same term as its functional equivalent in the international conventions - the term bribery.

- The concepts forming the dichotomy 'active - passive'

In the conceptual system of the UK Bribery Act (Sections 1 and 2) the same dichotomy 'active-passive' as in the international conventions exists. It is expressed by the following terms:

- offences of bribing another person,

- offences relating to being bribed.

In the Guidance, these two forms of offences are also denoted by the terms which coincide with the ones in the $\mathrm{CoE}$ convention: "The Act contains two general offences covering the offering, promising or giving of a bribe (active bribery) and the requesting, agreeing to receive or accepting of a bribe (passive bribery) at sections 1 and 2 respectively" (the Guidance, p. 8). In this way, the national terms are related to the international terminology enabling the reader to easily capture the links between the national and international legal settings.

- The concepts forming the dichotomy 'public - private'

In UK Bribery Act, the definitions of general offences of bribing another person and offences relating to being bribed do not differentiate between the offences committed in the public and private sectors. The general offences concern any person within the UK jurisdiction (the UK Bribery Act Articles 1, 2).

In addition to general offences, the UK Bribery Act specifies two additional bribery offences: bribery of foreign public officials and failure of commercial organisations to prevent bribery. These offences are special activities and are not to be regarded as functional equivalents of the investigated international concepts which are much more inclusive.

Thus, in the UK Bribery Act there are no separate concepts forming the dichotomy 'public-private' which is present in the international conventions. 
The analysis performed allows to develop the following scheme reflecting the system of bribery offences in the UK Bribery Act and their terminological denotations:

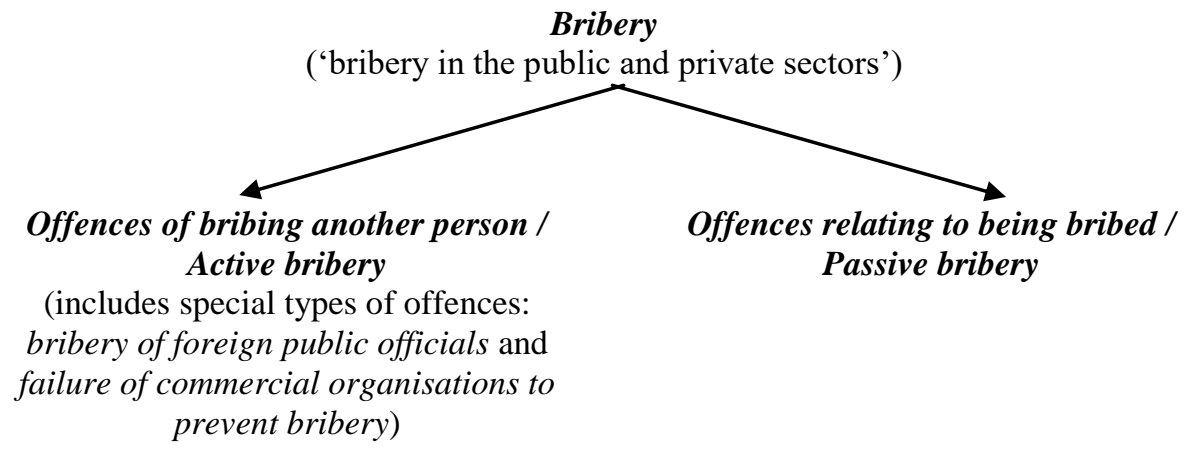

Fig. 3 Bribery offences in the UK Bribery Act

\subsection{Analysis of the national legal acts of Lithuania}

The present research is based on the criminal code of the Republic of Lithuania Lietuvos Respublikos Baudžiamasis kodeksas, 2000 (further the LT Criminal Code).

- The generic concept of bribery

The LT Criminal Code defines two forms of bribery offences in the LT Criminal Code which are included in the Chapter XXXIII Nusikaltimai ir baudžiamieji nusižengimai valstybès tarnybai ir viešiesiems interesams ('Serious and minor offences against public office and public interest') ${ }^{1}$. This chapter specifies the following offences:

- kyšininkavimas ('passive bribery'),

- prekyba poveikiu ('trading in influence'),

- papirkimas ('active bribery'),

- piktnaudžiavimas ('abuse of office'),

- neteisetas teisiu $i$ daikta i iregistravimas ("unlawful registration of rights to an item'),

- tarnybos pareigu neatlikimas ('failure to perform official duties').

However, there is no term referring to the generic concept of bribery and no definition of such concept. Thus, it may be concluded that such concept does not exist in the Lithuanian conceptual system of corruption related offences in the LT Criminal Code.

- The concepts forming the dichotomy 'active - passive'

The two forms of bribery offences specified in the LT Criminal Code form the dichotomy 'active-passive' in the same way as it is formed in the international conventions. The concepts referring to the different forms of bribery offences are expressed by the following terms:

\footnotetext{
${ }^{1}$ In the current section the analysed Lithuanian terms of the LT Criminal Code are presented with the English counterparts provided by the authors of the article seeking the closest equivalents. The suggested counterparts do not always coincide with the ones in the official English translations of the LT Criminal Code. The presented English translations of the definitions do not fully coincide with the ones in the official English translation of the code either.
} 
- kyšininkavimas ('passive bribery'),

- papirkimas ('active bribery').

- The concepts forming the dichotomy 'public - private'

As stated above, bribery offences are included in the chapter of the LT Criminal Code devoted to offences of public officials and public interest (ibid., Chapter XXXIII). Therefore, these offences concern mainly activities involving public officials, i.e. bribery activities in the public sector. The terms denoting public officials are included in both types of bribery definitions:

- kyšininkavimas ('passive bribery') is performed by "a public official or a person of equal status who, for own benefit or for the benefit of other persons, directly or indirectly accepts, promises or agrees to accept a bribe, demands or provokes giving it for a lawful act or inaction in exercising his powers" (ibid.,Chapter XXXIII, Article 225).

- papirkimas ('active bribery') is performed by "a person who, whether directly or indirectly, offers, promises to give or gives a bribe to a public official or a person of equal status for a desired lawful act or inaction in exercising his powers or to an intermediary seeking to achieve the same results" (ibid., Chapter XXXIII, Article 227).

The cited Chapter provides the explanations of the terms a public official and a person of equal status. According to them, a person of equal status to a public official is "a person holding appropriate powers at a foreign state institution, an international public organisation or international judicial institutions, also official candidates for such office" as well as "a person who works at any state, non-state or private body, undertaking or organisation or engages in professional activities and holding appropriate administrative powers or has the right to act on behalf of this body, undertaking or organisation or provides public services" (ibid., Article 230). The second explanation allows to interpret bribery offences as encompassing both activities in the public and in the private sector. However, the title of the Chapter indicates that the focus of this chapter is the offences in the public sector.

It can be concluded that bribery offences in the private sector are not specifically defined and the dichotomy 'public-private' does not exist in the LT Criminal Code. Thus, the conceptual system of the LT Criminal Code includes two concepts referring to two different forms of bribery offences, but it does not contain a generic concept of bribery. The following scheme reflecting the Lithuanian micro-system of bribery offences may be provided:

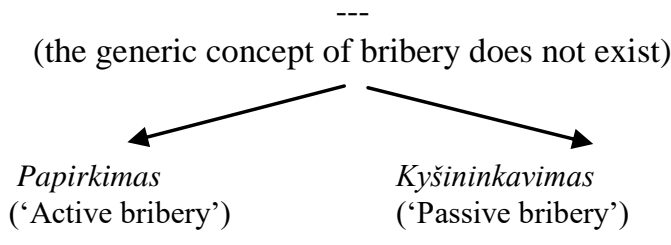

Fig. 4 Bribery offences in the LT Criminal Code 


\subsection{Analysis of the national legal acts of the Russian Federation}

To analyse conceptualisation and denotation of bribery offences in the Russian legal setting, the criminal code of the Russian Federation Уголовный кодекс Российской Федераичu, 1996 (further the RU Criminal Code) was chosen.

- The generic concept of bribery

The RU Criminal Code defines various types of bribery offences which are included in two sections: Преступления в сфере экономики ('Crimes in the Sphere of Economics', Section VIII) and Преступления против государственной власти ('Crimes against State Power', Section X) $)^{2}$.

The terms used to denote bribery in the sections are подкуn, коммерческий подкуn and взяточничество. However, there is neither a term referring to the generic concept of bribery nor a definition of such concept in the code. Hence, it may be concluded that the RU Criminal Code does not contain the generic concept of bribery encompassing all its forms and types.

- The concepts forming the dichotomy 'public - private'

In the RU Criminal Code there is a clear dichotomy between the bribery offences in the private and public sectors. Offences in the private sector are described in Section VIII, Chapter 23 Преступления против интересов службы в коммерческих и иных организациях ('Crimes against the Interests of Service in Profit-making and Other Organisations'), Articles 204, 204.1, 204.2. They concern direct bribery activities and intermediation in bribery activities involving "a person who discharges managerial functions in a profit-making or any other organisation" (RU Criminal Code, Article 204). The concept of bribery in the private sector is denoted by the term коммерческий подкуп ("commercial bribery').

Offences in the public sector are described in Section X, Chapter 30 Преступления против государственной власти, интересов государственной службы и службы в органах местного самоуправления ('Crimes against State Power and the Interests of the Civil Service and the Service in Local Self-government Bodies'), Articles 290, 291, 291.1, 291.2. They concern direct bribery activities and intermediation in bribery activities involving "a functionary, a foreign functionary or a functionary of a public international organisation" (RU Criminal Code, Articles 290, 291). The concept of bribery in the public sector is denoted by the term взяточничество used in Article 291.1 Посредничество во взяточничестве ('Mediation in Bribery') and Article 291.2 Мелкое взяточничество ('Minor Bribery').

In addition, Sections VIII and X contain articles on special types of bribery: bribery of contractors and members of commissions concerning purchase of commodities/services for state/municipality needs, provocation of bribery concerning purchase of commodities/services for state/municipality needs and bribery concerning testimonies in court proceedings (The RU Criminal Code, Articles 200.5, 309). However, these bribery activities are special offences and therefore are beyond the scope of the research which focuses on functional equivalents of the investigated international concepts which are much more inclusive.

\footnotetext{
${ }^{2}$ In the current section, the translations of most analysed Russian terms and definitions in the RU Criminal Code are presented as provided in the official English translation of the RU Criminal Code. However, some terms (e.g. получение взятки 'passive bribery', дача взятки 'active bribery') are translated by the authors of the article by the counterparts which do not coincide with the ones in the official English translation of the code.
} 
- The concepts forming the dichotomy 'active - passive'

In the RU Criminal Code there is also a clear dichotomy between two forms of bribery activities performed by a briber and a bribe towards each other in the same bribery situation. The same dichotomy exists in bribery situations both in the public and in the private sector:

- Private sector:

"The illegal transfer of money, securities or any other assets to a person who discharges managerial functions in a profit-making or any other organisation, and likewise unlawful rendering of property-related services, granting other property rights to him/her for commission of actions (inaction) in the interests of the giver, in connection with the official position held by this person..."

"The illegal receipt of money, securities or any other assets by a person who discharges managerial functions in a profit-making or any other organisation, and likewise the illegal use of property-related services or exercise of other property rights for omission of actions (inaction) in the interests of the giver, in connection with the official position held by this person..." (ibid., Article 204).

- Public sector:

"Bribe-taking by a functionary, a foreign functionary or a functionary of a public international organisation in person or through an intermediary, in the form of money, securities or other assets or in the form of unlawful rendering thereto services of property nature, or granting of other property rights, for actions (inaction) in favour of a bribe-giver or the persons he/she represents, if such actions (inaction) form part of the functionary's official powers or if the latter, by virtue of his/her official position, may further such actions (inaction), and also for overall patronage or connivance in the civil service..." (ibid., Article 290).

"Giving a bribe to a functionary, a foreign functionary or a functionary of a public international organisation in person or through an intermediary..." (ibid., Article 291).

Expression of the dichotomy 'active - passive' is different in the articles on bribery in the private sector and bribery in the public sector. In the articles on private bribery, the forms of bribery, forming the opposition 'active - passive' do not have separate terminological denotations though they are described in separate definitions and evidently function as separate concepts. The articles on public bribery, on the other hand, do contain separate terminological denotations of active and passive bribery. They are as follows: получение взятки ('passive bribery'), дача взятки ('active bribery'). Interestingly enough, the analysis reveals that the RU Criminal Code does not contain a hypernymic term denoting the generic concept encompassing all forms and types of bribery.

In the RU Criminal Code, the dichotomy 'private - public' of bribery offences is expressed by two different terms: коммерческий подкуn - взяточничество. The dichotomy 'active - passive' exists in both private and public bribery definitions. However, it is expressed only partially: offences in the public sector have different terminological denotations reflecting the dichotomy relations while offences in the private sector do not: 
Коммерческий подкуп

('bribery in the private sector')

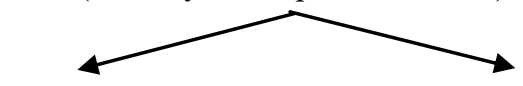

No special term

for the existing

concept of active bribery
No special term for the existing concept of passive bribery
Взяточничество

('bribery in the public sector')

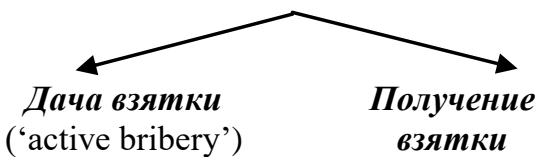

('passive bribery')

Fig. 5 Bribery offences in the LT Criminal Code

\subsection{Establishment of the terminological counterparts in the investigated international and national legal settings}

The analysis of conceptualisation and denotation of bribery offences in the international and national legal settings confirms that every legal setting has its own conceptual system and therefore absolute equivalence between concepts of different legal settings is not possible. However, it is possible to determine functional equivalents performing similar functions in different settings and thus to select the most appropriate terminological counterparts in different languages. This analysis focused on the concepts performing the following functions:

- generic concept of all bribery offences,

- bribery concepts forming the dichotomy 'public - private',

- bribery concepts forming the dichotomy 'active - passive'.

The results of the analysis allow to establish the following terminological counterparts in the investigated legal settings:

Table 2 The hypernymic term denoting the generic concept of bribery

\begin{tabular}{|l|c|c|c|}
\hline Legal setting & EN & LT & RU \\
\hline International & Bribery & Kyšininkavimas & Подкyn \\
\hline National & Bribery & - & - \\
\hline
\end{tabular}

Table 3 The co-hyponymic terms expressing the dichotomy 'public - private'

\begin{tabular}{|l|c|c|c|}
\hline Legal setting & EN & LT & RU \\
\hline International & Bribery & Kyšininkavimas & Подкуп \\
& [in the public sector] & [valstybiniame sektoriuje] & [в публичном \\
& - & - & секторе] \\
& Bribery & Kyšininkavimas & - \\
& in the private sector & privačiame sektoriuje & Подкуn \\
& - & & в частном секторе \\
\hline National & & & Коммерческий \\
& & & подкуп \\
& & & - \\
& & & Взяточничество \\
\hline
\end{tabular}


Table 4 The co-hyponymic terms expressing the dichotomy 'active - passive'

\begin{tabular}{|c|c|c|c|}
\hline Legal setting & EN & $\mathrm{LT}$ & RU \\
\hline International & $\begin{array}{c}\text { Active bribery } \\
- \\
\text { Passive bribery }\end{array}$ & $\begin{array}{c}\text { Aktyvusis } \\
\text { kyšininkavimas } \\
\text { Pasyvusis } \\
\text { kyšininkavimas }\end{array}$ & $\begin{array}{c}\text { Активный подкуn } \\
- \\
\text { Пассивный подкуn }\end{array}$ \\
\hline National & $\begin{array}{c}\text { Offences of } \\
\text { bribing another person / } \\
\text { Active bribery } \\
- \\
\text { Offences } \\
\text { relating to being bribed / } \\
\text { Passive bribery }\end{array}$ & $\begin{array}{c}\text { Papirkimas } \\
- \\
\text { Kyšininkavimas }\end{array}$ & $\begin{array}{c}\text { only about offences } \\
\text { in the public sector: } \\
\text { Дача взятки } \\
\quad- \\
\text { Получение взятки }\end{array}$ \\
\hline
\end{tabular}

The results of the analysis reveal the immense incongruity among the investigated legal settings, both their conceptual systems and principles of terminological denotation. Simultaneously, it enables to establish links between different legal settings and search for the most appropriate counterparts in legal translations.

\section{CONCLUSION}

The bribery terminology analysis focused on two international conventions (UN Convention and CoE Convention) and national legal acts of the UK, Lithuania and Russia. It disclosed important conceptual and formal differences among the international and national conceptual-terminological systems of bribery offences: the dissimilarities between the international setting and every investigated national setting and the discrepancies among the investigated national settings (the UK, Lithuanian and Russian). The immense incongruities are caused by different conceptualisation of the same aspect of social life in distinct legal settings and different terminology of the same language used in the national legal acts and in the translations of the international conventions. The most striking revelation for the LSP learners and teachers is the fact that there is no term referring to the generic concept of bribery in the Lithuanian and Russian national legal acts.

The case studies of this kind may be used both for legal language, translation and terminology studies. Contrastive case studies of legal terms require sufficient language skills and analytical abilities to tackle complicated material, to capture the main aspects of the investigated material, to systematise and generalise the collected data. Such case studies enable students to gain encyclopaedic knowledge on terminology in different legal settings which is necessary to better understand the functions of terms and consequently, to use them correctly. That is undoubtedly, the most important goal of LSP studies.

Concomitantly, such case studies raise students' awareness of legal translation challenges and enhances their understanding of the importance of cognitive and communicative approach to the translation material: legal translation is impossible without knowledge of relevant legal systems and assessment of the recipients and functions of the target text. The translator needs to be aware of the conceptual-terminological systems in the source and target legal languages (as the case study in this paper shows there can be several of them in every language) and adhere to one of them in a translation assignment. 
Contrastive case studies of legal terms also enable to assess translation of international documents into national languages and translation of national documents into English. They raise essential terminology unification issues for further studies: whether it is possible to develop a coherent conceptual-terminological system used in the same language both nationally and internationally and whether unification of terminology used in different national frameworks is possible at all in the legal domain.

\section{REFERENCES}

Argandoña, Antonio. 2003. Private-to-Private Corruption (Working Paper). University of Navarra. IESE Business School. http://www.iese.edu/research/pdfs/DI-0531-E.pdf (Accessed: 14 January 2019).

Bajčić, Martina. 2017. New Insights into the Semantics of Legal Concepts and the Legal Dictionary. John Benjamins Publishing Company.

Biel, Łucja and Jan Engberg. 2013. „Research Models and Methods in Legal Translation”. Linguistica Antverpiensia, New Series - Themes in Translation Studies, 12:1-11.

Cabré, M. Teresa Castellvi. 1999. Terminology: Theory, Methods and Applications. John Benjamins Publishing Company.

De Groot, and Conrad J.P. van Laer. 2007. The Dubious Quality of Legal Dictionaries”. In Thelen M. and B. Lewandowska-Tomaszczyk (Eds.) Translation and Meaning, Part 7:173-187. https://pub.maastrichtuniversity.nl/a0a6a21f-8233-4b09-894c-923ab223deac? fid=9112 (Accessed: 14 January 2019).

Galdia, Marcus. 2003. "Comparative Law and Legal Translation". The European Legal Forum. Forum iuris communis Europae, 1:1-4.http://www.simons-law.com/library/pdf/e/ 355.pdf (Accessed: 14 January 2019).

Jackson, Howard and Etienne ZeAmvela. 2012. Words, Meaning and Vocabulary. An Introduction to Modern English Lexicology. London, New York: Continuum International Publishing Group.

Pamela, Faber (ed.). 2012. A Cognitive Linguistics View of Terminology and Specialized Language. Berlin, Boston: De Gruyter Mouton.

Pardo, Italo (Ed.). 2016. Between Morality and the Law: Corruption, Anthropology and Comparative Society. Routledge.

Roche, Christophe, Marie Calberg-Challot, Luc Damas, Philippe Rouard. 2009. Ontoterminology: A new paradigm for terminology. International Conference on Knowledge Engineering and Ontology Development, Oct 2009, Madeira, Portugal. 2009:321-326. https://hal.archives-ouvertes.fr/hal-00622132/document (Accessed: 14 January 2019).

Sandrini, Peter. 2009. "The Parameters of Multilingual Legal Communication in a Globalized World”. Comparative Legilinguistics. International Journal for Legal Communication, $1: 35-49$.

Šarčević, Susan. 1997. New Approach to Legal Translation. The Hague/London/Boston: Kluwer Law International.

Šeškauskienė, Inesa. 2013. Ways with Words. Insights into the English Lexicon and Some Cross-linguistic Aspects of Study. Vilnius: Vilnius University Publishing House.

TI Anti-Corruption Glossary - Transparency International Anti-Corruption Glossary. https://www.transparency.org/glossary (Accessed: 14 January 2019). 


\section{LEGAL ACTS:}

The CoE Convention - Criminal Law Convention on Corruption. Council of Europe (adopted 1999, entered into force 2002). European Treaty Series, No. 173.

The CoE Convention (Lithuanian translation) - Baudžiamosios teisès konvencija dèl korupcijos. Europos Taryba. Valstybès žinios, 2002-03-01, Nr. 23-853.

The CoE Convention (Russian translation) - Конвенция Совета Европьл об уголовной ответственности за коррупџию. Страсбург, 27 января 1999 года. https://www.coe. int/en/web/conventions/full-list/-/conventions/rms/090000168007f58c (Accessed: 14 January 2019).

The Guidance - The Bribery Act 2010. Guidance about procedures which relevant commercial organisations can put into place to prevent persons associated with them from bribing (Section 9 of the Bribery Act 2010). https://www.justice.gov.uk/downloads/ legislation/bribery-act-2010-guidance.pdf (Accessed: 14 January 2019).

The LT Criminal Code - Lietuvos Respublikos Baudžiamojo kodekso patvirtinimo ir ìsigaliojimo įstatymas. Valstybès žinios. 2000-10-25, Nr. 89-2741.

The LT Criminal Code (English translation) - Republic of Lithuanian Law on the Approval and Entry into Force of the Criminal Code.https://e-seimas.lrs.lt/portal/legalAct/lt/TAD/ TAIS.353941?jfwid=-19syzwy5my (Accessed: 14 January 2019).

The RU Criminal Code - Уголовный кодекс Российской Федерации, 1996. http://pravo. gov.ru/proxy/ips/?docbody\&nd=102041891 (Accessed: 14 January 2019).

The RU Criminal Code (English translation) - The Criminal Code Of The Russian Federation (1996, amended 2012). https://www.legislationline.org/documents/section/criminalcodes/country/7/Russian\%20Federation/show (Accessed: 14 January 2019).

The UK Bribery Act - The Bribery Act 2010. Ahttp://www.legislation.gov.uk/ukpga/ 2010/23/contents (Accessed: 14 January 2019).

The UN Convention - The United Nations Convention against Corruption (adopted 2003, entered into force 2005). United Nations Treaty Series, No. 2349.

The UN Convention (Lithuanian translation) - Jungtinių Tautų konvencija prieš korupciją. Valstybès žinios, 2006-12-14, Nr. 136-5145.

The UN Convention (Russian translation) - Конвенция Организации Объединенньх Наций против коррупции. Принята резолюцией 58/4 Генеральной Ассамблеи от 31 октября 2003 года. http://www.un.org/ru/documents/decl_conv/conventions/corruption.shtml (Accessed: 14 January 2019). 